\title{
Growth rate, condition, and shell shape of Mytilus galloprovincialis: responses to wave exposure
}

\author{
C. Nina Steffani*, George M. Branch
}

Marine Biology Research Institute, Zoology Department, University of Cape Town, Rondebosch 7701, South Africa

\begin{abstract}
Growth rates, condition indices and shell shapes of Mytilus galloprovincialis, an invasive alien mussel that has colonised the west coast of South Africa, were measured at a series of sites with different wave exposure regimes in 2 regions $500 \mathrm{~km}$ apart. Wave action at the sites was determined by maximum wave-force dynamometers. M. galloprovincialis grew faster and had higher condition values on exposed than on sheltered shores, probably due to higher food availability at sites with greater water flow. Growth rates and condition values, however, declined at sites experiencing extreme wave action. This resulted in a polynomial relationship between the growth coefficient $K$, and wave force. Mussels grew slower in the southern region, where food concentrations are lower. The shells of $M$. galloprovincialis tended to be lower and narrower at exposed sites, perhaps reducing the effect of hydrodynamic forces. Mussel shells were thickest on sheltered and extremely exposed shores. The results are discussed in the context of the impact that M. galloprovincialis is likely to have on indigenous species. Because M. galloprovincialis is scarce and slow-growing at sheltered sites, its competitive effects there are likely to be minimal, whereas on exposed sites its density, growth and condition are highest and its effects will peak, diminishing again at extremely exposed sites.
\end{abstract}

KEY WORDS: Growth rate $\cdot$ Condition $\cdot$ Mussels $\cdot$ Wave force $\cdot$ Rocky intertidal $\cdot$ South Africa

\section{INTRODUCTION}

Life-history patterns and population characteristics of mytilid mussels vary greatly among geographical sites and at different positions on the shore. Differences in environmental conditions impacting on the mussels account for most of the variability, including differences in spawning periods, reproduction and growth (see reviews in Seed 1980, Suchanek 1985, Griffiths \& Griffiths 1987, Seed \& Suchanek 1992). Among the environmental conditions, temperature and aerial exposure (as a function of the tidal elevation) are key determinants of the population dynamics of mussels (Griffiths \& Griffiths 1987). The degree of wave exposure is, however, also an important physical factor influencing the characteristics of mussel populations.

Intense wave action imposes high hydrodynamic forces on mussels and puts them at risk of dislodge- ment and damage to their shells (Paine \& Levin 1981, Denny 1987). Mussels can respond to the risk of dislodgment by increasing their attachment strength at wave-exposed shores (Price 1982, Witman \& Suchanek 1984, Hunt \& Scheibling 2001). Attachment strength depends on the number and size of byssus threads anchoring mussels to the substratum (Bell \& Gosline 1997). These threads decay over time and must be replaced to maintain attachment, and the process of replacement can form 8 to $15 \%$ of a mussel's total energy expenditure (Griffiths \& King 1979b, Hawkins \& Bayne 1985). An increase in shell thickness can protect mussels from the destructive effects of wave action (Fox \& Coe 1943, Raubenheimer \& Cook 1990). This is also metabolically costly, since 25 to $50 \%$ of the total body energy can be tied up in the shell (Jørgensen 1976, Griffiths \& King 1979b, Gardner \& Thomas 1987).

In contrast to these negative effects of wave action, high-energy shores experience greater water flow, 
which is thought to deliver more food to the shore (Bertness et al. 1991, Sanford et al. 1994, Bustamante \& Branch 1996, Dahlhoff \& Menge 1996, Sanford \& Menge 2001). Since food provides the energy for production, its availability is probably the single most important factor controlling production. For growth and reproduction to take place, the energy ingested as food must exceed the costs of metabolic maintenance. If energy intake is less than those costs, mussels must use body reserves and negative growth, or 'degrowth', occurs. If the energy content of the absorbed ration exceeds the metabolic costs, the surplus in energy may be deposited as byssus, shell and body tissues, including gonads (Hawkins \& Bayne 1992).

Along a gradient of wave force, trade-offs probably exist between protection from the destructive force of waves, but lower food supply at more sheltered sites, and higher food supply, but greater risk of dislodgment and damage, at more exposed sites. These trade-offs are likely to result in differences in the availability of surplus energy and in the partitioning of this energy into byssus, shell and/or flesh production.

The aim of this study was to investigate possible differences in the population dynamics of the alien invasive Mytilus galloprovincialis at sites differing in their degree of wave exposure. Specifically, we investigated differences in growth rates, condition (the relation of flesh weight to shell weight) and shell morphology.

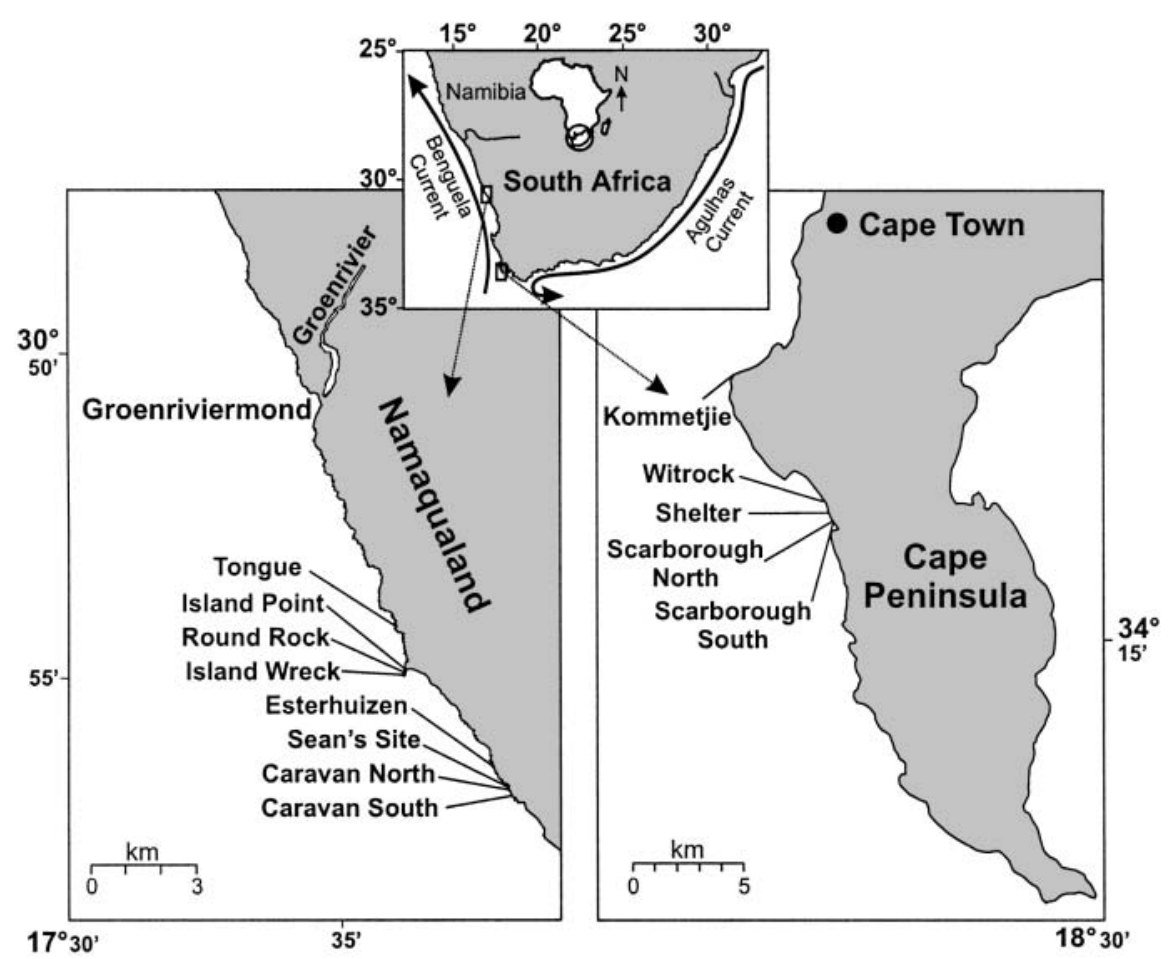

Fig. 1. Study sites on the Cape Peninsula and Groenrivier on the west coast of South Africa
Sites were selected to cover as broadly as possible the entire wave-exposure range occupied by $M$. galloprovincialis on the west coast of South Africa, and the large-scale applicability of the results was tested by working in 2 regions of the coast separated by $500 \mathrm{~km}$. It was hypothesized that (1) growth rates will be faster and (2) condition will be better on exposed compared to more sheltered shores, and (3) shell morphology will differ in a manner that reduces resistance to water flow at exposed sites. The findings are not only of interest in terms of the energetics of the mussel, but provide insight into the likely competitive effects of $M$. galloprovincialis on indigenous species and how this is affected by wave action.

\section{MATERIALS AND METHODS}

Study sites and wave-force measurements. The study sites ranged in their degree of wave exposure from sheltered to very exposed, and they were located in 2 regions on the west coast of South Africa, approximately $500 \mathrm{~km}$ apart. In the first region, Groenrivier in Namaqualand, observations were made at the following 8 study sites: Tongue, Island Point, Round Rock, Island Wreck, Esterhuizen, Sean's Site, Caravan North and Caravan South. The second region was situated on the Cape Peninsula, where there were 5 study sites: Kommetjie, Witrock, Shelter, Scarborough North and Scarborough South (Fig. 1). Intertidal wave forces at the sites were measured using a maximum wave-force dynamometer. A detailed description of the device and the calculations involved can be found in Palumbi (1984). On the Cape Peninsula, 10 devices were simultaneously mounted to the rock on the low shore at each site on 3 different randomly selected occasions spanning the year, left for $24 \mathrm{~h}$ (2 full tidal cycles), and then retrieved. Each device provided a single measurement of maximum wave force during the 2 tidal cycles, which was expressed in $\mathrm{N} \mathrm{m}^{-2}$. Wave forces at the sites at Groenrivier were measured using the same method, but on 5 occasions (also randomly selected to span the year) and are from Steffani \& Branch (2002), except for the measurements for Round Rock, which are from Steffani (2001).

Growth rate. Growth rates of Mytilus galloprovincialis were measured at all sites. In October 1997, ca. 300 mussels 
site $^{-1}$, covering a size range from $15 \mathrm{~mm}$ upwards, were randomly chosen in the low-shore mussel bed for growth measurements. The ventral margin of each mussel (opposite the umbo) was marked in situ by filing a small notch into the shell edge without disturbing the soft tissue. Similar methods of marking mussels have proven successful (Dehnel 1956, Seed 1976). Six months later (April 1998), the marked mussels were collected and brought to the laboratory. Recovery rate of notched mussels ranged from 27 to $57 \%$. The shell length (i.e. the anatomical height) of the mussels was measured to the nearest $0.1 \mathrm{~mm}$ with Vernier calipers from the umbo to the initial ventral margin (marked by the notch) and from the umbo to the final ventral margin of the shell. The distance from the umbo to the notch represents the initial length at the time when the mussels were marked. The second measurement incorporates the shell-length increment during the 6 mo.

For each site, Ford-Walford plots were derived by regressing the final shell length $\left(L_{t+6 \mathrm{mo}}\right)$ on the initial shell length $\left(L_{t}\right)$, with the regression equation

$$
L_{t+6 \mathrm{mo}}=m L_{t}+i
$$

where $m$ is the slope and $i$ the intercept on the $y$-axis. Constants from these Ford-Walford plots were then used to calculate von Bertalanffy growth curves, which are used extensively for bivalve taxa (Seed 1980), and are described by

$$
L_{t}=L_{\infty}\left(1-\mathrm{e}^{-K t}\right)
$$

where $L_{t}$ is the length at age $t_{1} L_{\infty}$ the asymptotic length determined by using $i /(1-m)$ from the Ford-Walford plot, and $K$ the growth coefficient based on 6-monthly growth calculated using $-\ln m$.

In using growth measurements determined for a period of 6 mo (during the austral summer) to establish annual growth curves, we assumed that Mytilus galloprovincialis does not exhibit seasonal growth, even though it is common for bivalves from temperate regions to grow faster in particular seasons (Griffiths \& Griffiths 1987). Our assumption was based on the facts that (1) the water temperature on the west coast of South Africa does not vary with the seasons, averaging $12^{\circ} \mathrm{C}$ over most of the year (Field \& Griffiths 1991), and (2) particulate organic matter (POM) arrives at rocky shores at Groenrivier at a consistently high level all year round (Bustamante \& Branch 1996). Van Erkom Schurink \& Griffiths $(1991,1993)$ have also previously found that shell growth of $M$. galloprovincialis proceeds regularly throughout the year, and the lack of growth rings in the shell of another west coast mussel, Aulacomya ater, supports this assumption further (Griffiths \& King 1979b). We did test this assumption at one site, Island Wreck. Two sets of mussels, one in the austral summer and one in the austral winter, were marked in situ as described above and each set left at the shore for 6 mo. For each season, Ford-Walford growth regressions were established and tested for differences by applying Student's $t$-test to compare the slopes and elevations of the 2 lines. No difference was found between seasons (Ford-Walford regressions: slope $t_{47}=-0.247, \mathrm{p}>0.5 ;$ elevation $t_{47}=-1.217, \mathrm{p}>$ 0.2 ). This supports that the assumption of constant growth for M. galloprovincialis on the west coast of South Africa and indicates that the 6-monthly FordWalford equations could be used to derive annual growth curves.

Condition and shell shapes. Condition indices for Mytilus galloprovincialis were determined at all sites in both regions every 3 mo for $1 \mathrm{yr}$, starting in April 1998. At each site and on each sampling date, 50 randomly selected mussels $\geq 10 \mathrm{~mm}$ were collected from the low-shore mussel bed. In the laboratory, the maximum shell length, width (both valves) and height of each mussel were measured to the nearest $0.1 \mathrm{~mm}$. The mussels were then placed in boiling water until the shells opened, the flesh separated from the shell, and the byssus including the gland removed. The flesh and the shell were oven dried for $4 \mathrm{~d}$ at $50^{\circ} \mathrm{C}$, or until the weight was constant. Flesh and shell were weighed to $0.1 \mathrm{mg}$. The condition index was calculated by the following equation, taken from Davenport \& Chen (1987):

$$
\text { CI }=\frac{\text { dry flesh weight }(\mathrm{mg})}{\text { Shell weight }(\mathrm{mg})} \times 100
$$

The data for shell length, width and height were used to investigate differences in shell shapes of Mytilus galloprovincialis among sites. To obtain an index of shell thickness, the method described by Raubenheimer \& Cook (1990) was followed. The product of length and height of the shells was taken to be proportional to the surface area, and shell thickness was then estimated from the relationship between surface area and shell weight.

Statistical analyses. The data were tested for normality and homogeneity of variances by a KolmogorovSmirnov 1-sample test and Levene's test, respectively. If necessary, data were log-transformed to meet these assumptions. The significance level for all analyses was set at 0.05 . Unless otherwise stated, statistical analyses were conducted with Statistica 5.5 for Windows (StatSoft).

The wave forces at the 5 sites on the Cape Peninsula were measured at randomly chosen dates, which resulted in a 2-way mixed model design with Date as a random effect and Site as a fixed effect. This design was analysed by variance-components estimation. The ANOVA-based expected mean squares method (Vari- 


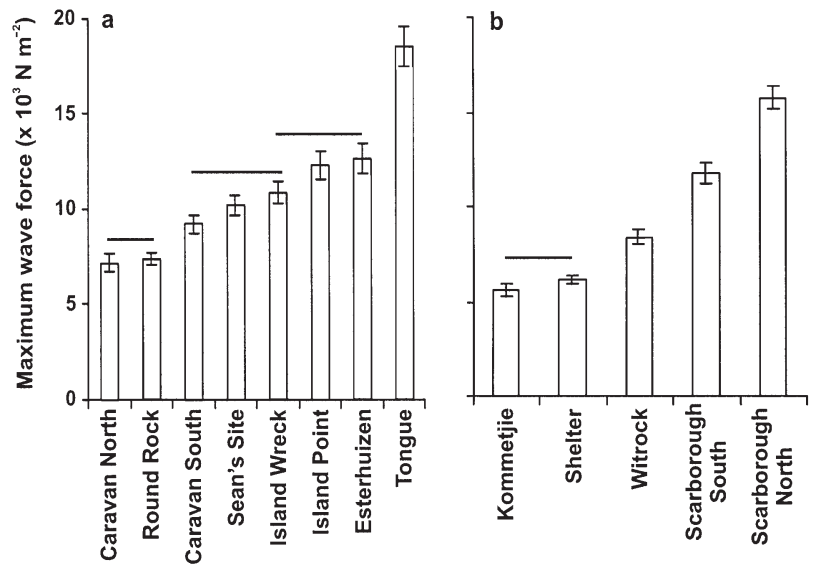

Fig. 2. Maximum wave forces (mean $\pm \mathrm{SE}$ ) at (a) 8 sites at Groenrivier $(\mathrm{n}=6)$ and (b) 5 sites on the Cape Peninsula $(n=3)$. Solid lines above the bar columns connect sites that were not significantly different $(p>0.05)$

ance Components Module, Statistica 5.5) provides an integrative approach for the estimation of variance components, because ANOVA techniques can be used to estimate the variance of the random factor and the components of variation in the dependent variable attributable to the random factor and to test whether the dependent variable has a significant component of variation for the random effect or the interaction of the random and the fixed factor. The significances of the variance components and of the fixed effect Site were tested using Satterthwaite's method of denominator synthesis for constructing error terms (Satterthwaite 1946). This method can result in fractional degrees of freedom, which indicates that fractions of sources of variation were used in synthesizing appropriate error terms.

Some of the wave-force dynamometers were lost during each measurement period, resulting in an unbalanced design, which makes estimates of the mean squares sensitive to heterogeneous variances. However, the implementation of Satterthwaite's approximation by Statistica takes care of the problem of heterogeneous variances. Differences among sites were further analysed by multiple comparisons Tukey HSD tests for unequal sample sizes.

Differences in growth rates among the sites within each region were analysed by comparing the slopes and elevations of the Ford-Walford growth regressions using ANCOVA, followed by post-hoc Tukey tests for comparisons among slopes. When the slopes were homogeneous (not significantly different), comparisons among elevations were conducted. Differences in the relationships describing the shell shape of Mytilus galloprovincialis were investigated for each region following the same procedure.

Differences in condition indices between sites and over time were analysed for each region using a 2-way Model-I ANOVA. This was followed by post-hoc multiple-comparison Tukey HSD tests. In case of significant interactions, the means of one factor were compared separately at each level of the other factor and vice versa (Underwood 1997), and the sequential Bonferroni correction was applied to compensate for the number of tests conducted (Peres-Neto 1999).

\section{RESULTS}

\section{Wave force}

The maximum wave-force measurements at the sites on the Cape Peninsula exhibited a clear gradient in wave exposure. Kommetjie was the most sheltered site, followed in order by Shelter, Witrock, Scarborough South and Scarborough North, which was the most exposed site (Fig. 2b). The variance-components analysis showed that the components of variance in the dependent variable (wave force) attributable to the interaction between the factors (Site $\times$ Date) and to the random factor (Date) were small (0.07519 and 0.10436, respectively) and had no significant effects $\left(F_{8,105}=\right.$ $0.838, \mathrm{p}=0.572$, and $F_{2,7.73}=2.353, \mathrm{p}=0.159$, respec-

Table 1. Mytilus galloprovincialis. Constants of the Ford-Walford growth regressions and the von Bertalanffy growth curves at (a) Groenrivier and (b) Cape Peninsula. $m$ : slope; $i$ : intercept at $y$-axis; $\mathrm{r}^{2}$ : coefficient of determination; $L_{\infty}$ : asymptotic length $(\mathrm{mm}) ; K$ : growth coefficient (6-monthly growth)

\begin{tabular}{|lccccc|}
\hline Site & \multicolumn{3}{c}{$\begin{array}{c}\text { Ford-Walford } \\
\text { m }\end{array}$} & \multicolumn{3}{c}{ von Bertalanffy } \\
& & & $\mathrm{r}^{2}$ & $L_{\infty}$ & $K$ \\
\hline (a) Groenrivier & & & & & \\
Caravan North & 0.908 & 6.749 & 0.974 & 73.6 & 0.096 \\
Round Rock & 0.912 & 6.034 & 0.986 & 68.5 & 0.092 \\
Caravan South & 0.903 & 6.263 & 0.970 & 64.5 & 0.102 \\
Sean's Site & 0.875 & 9.118 & 0.975 & 73.1 & 0.133 \\
Island Wreck & 0.884 & 9.847 & 0.978 & 85.2 & 0.123 \\
Island Point & 0.820 & 14.262 & 0.969 & 79.2 & 0.198 \\
Esterhuizen & 0.824 & 11.097 & 0.949 & 63.2 & 0.193 \\
Tongue & 0.929 & 4.637 & 0.954 & 65.4 & 0.078 \\
(b) Cape Peninsula & & & & & \\
Kommetjie & 0.967 & 1.889 & 0.992 & 58.1 & 0.033 \\
Shelter & 0.925 & 5.044 & 0.995 & 67.7 & 0.077 \\
Witrock & 0.912 & 5.514 & 0.970 & 62.3 & 0.093 \\
Scarborough South & 0.922 & 6.277 & 0.941 & 80.9 & 0.081 \\
Scarborough North & 0.944 & 3.719 & 0.979 & 66.5 & 0.058 \\
\hline
\end{tabular}


tively). The fixed factor (Site), on the other hand, had a significant effect, revealing differences among sites $\left(F_{4,7.16}=142.861, \mathrm{p}<0.001\right)$. This was followed by Tukey tests, showing that all sites were significantly different from each other $(\mathrm{p}<0.05)$ except the 2 most sheltered sites, Kommetjie and Shelter $(p>0.05)$. The data for wave forces at the 8 sites at Groenrivier were analysed in a similar manner. Again, there was a clear gradient of wave action among the sites, spanning almost a 3-fold difference between the extremes (Fig. 2a). Tukey tests showed that 4 groups of sites could be recognised statistically.

\section{Growth rates of Mytilus galloprovincialis at different wave forces}

The von Bertalanffy growth curves of Mytilus galloprovincialis at the 2 regions varied considerably among the sites with different wave exposures. In both regions, mussels at the sites in the middle of the waveexposure scale (e.g. Scarborough South on the Cape Peninsula; Island Wreck and Island Point at Groenrivier) exhibited the fastest growth rates. Mussels at sites to both extremes of the wave-force scale grew considerably slower (Fig. 3). This pattern becomes more obvious if the data are standardized to consider the shell lengths mussels achieved after 4 yr of growth. On this basis, at Groenrivier M. galloprovincialis grew to about $50-65 \mathrm{~mm}$ at the 4 moderately exposed sites (Sean's Site, Island Wreck, Island Point and Esterhuizen), but only to $37-40 \mathrm{~mm}$ at the 3 most sheltered sites (Caravan North, Round Rock and Caravan South) and $30 \mathrm{~mm}$ at the extremely exposed site (Tongue). A similar picture emerged for mussels on the Cape Peninsula, with highest values at sites with intermediate levels of wave action (Shelter, Witrock and Scarborough South) and lowest values for the more sheltered site (Kommetjie) and the most exposed site (Scarborough North).

The constants of the Ford-Walford growth regressions and the von Bertalanffy growth curves for both regions can be found in Table 1. Statistical comparisons of growth rates at Groenrivier showed that the Ford-Walford growth regressions of Mytilus galloprovincialis differed between all sites in either the slopes or the elevations. Only the growth rates of mussels at Round Rock and Caravan South, and at Sean's Site and Esterhuizen, did not differ from each other in terms of either their slopes or their elevations (Table 2a). On the Cape Peninsula, the FordWalford growth regression slopes of mussels were similar at all sites but the elevations differed between all sites except for Shelter and Witrock (Table 2b).
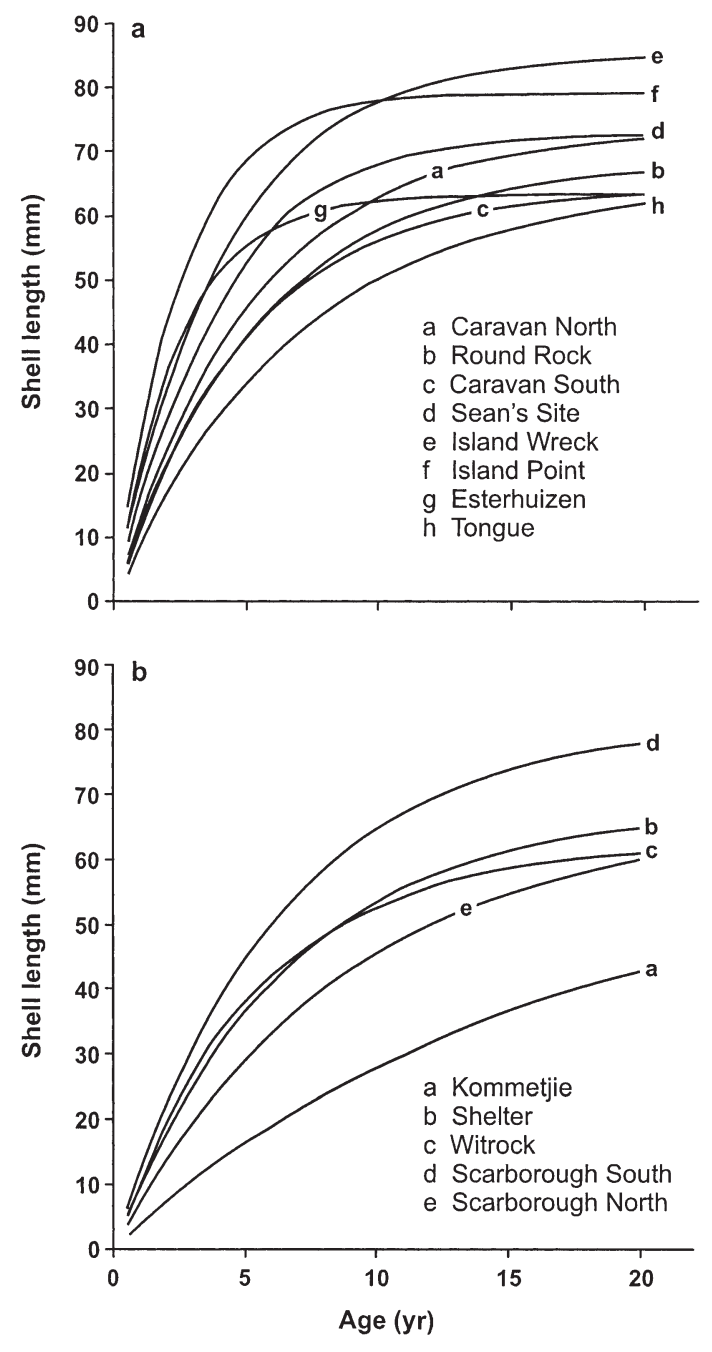

Fig. 3. Mytilus galloprovincialis. Von Bertalanffy growth curves at (a) Groenrivier and (b) Cape Peninsula. The sites are listed in sequence from least to most exposed

At Groenrivier, the growth coefficient $K$ of the mussels showed a significant polynomial relationship with wave force. The growth coefficient first increased with rising wave force, but declined at wave forces over $13 \times 10^{3} \mathrm{~N} \mathrm{~m}^{-2}$ (Fig. 4a); $72 \%$ of the variation was explained by differences in wave force. On the Cape Peninsula, a similar relationship was apparent, although it was not statistically significant (Fig. 4b).

A direct comparison between sites with similar exposures in the 2 regions was not possible, since no 2 sites had similar wave forces. Moreover, wave-force measurements at the 2 regions were not undertaken at the same dates, which might have confounded comparisons. However, an overall comparison showed that Mytilus galloprovincialis grew generally slower on the Cape Peninsula than at Groenrivier. The maximal growth coefficient achieved on the Cape Peninsula (Witrock, 
Table 2. Mytilus galloprovincialis. ANCOVA and Tukey tests among growth rates at (a) Groenrivier and (b) Cape Peninsula. Shared letters $(a, b, c, d$, e or f) indicate no significant dif-ference $(p>0.05)$ between slopes or elevations

\begin{tabular}{|c|c|c|}
\hline & $\begin{array}{c}\text { Comparisons } \\
\text { among slopes } \\
\text { ANCOVA }\end{array}$ & $\begin{array}{c}\text { Comparisons } \\
\text { among elevations }\end{array}$ \\
\hline \multicolumn{3}{|l|}{ (a) Groenrivier } \\
\hline$F$ & 8.975 & 93.677 \\
\hline $\mathrm{df}_{\text {pooled }}$ & 895 & 895 \\
\hline $\mathrm{p}$ & $<0.001$ & $<0.001$ \\
\hline \multicolumn{3}{|l|}{ Tukey tests } \\
\hline Caravan North & $\mathrm{ac}$ & $\mathrm{C}$ \\
\hline Round Rock & $\mathrm{a}$ & a \\
\hline Caravan South & $\mathrm{a}$ & a \\
\hline Sean's Site & $\mathrm{ac}$ & $\mathrm{b}$ \\
\hline Island Wreck & $\mathrm{ac}$ & d \\
\hline Island Point & $\mathrm{b}$ & $\mathrm{e}$ \\
\hline Esterhuizen & bc & $\mathrm{b}$ \\
\hline Tongue & $\mathrm{a}$ & $\mathrm{f}$ \\
\hline \multicolumn{3}{|l|}{ (b) Cape Peninsula } \\
\hline$F$ & 2.061 & 95.443 \\
\hline $\mathrm{df}_{\text {pooled }}$ & 712 & 712 \\
\hline p & $>0.05$ & $<0.001$ \\
\hline \multicolumn{3}{|l|}{ Tukey tests } \\
\hline Kommetjie & $\mathrm{a}$ & $\mathrm{a}$ \\
\hline Shelter & a & $\mathrm{b}$ \\
\hline Witrock & $\mathrm{a}$ & $\mathrm{b}$ \\
\hline Scarborough South & a & C \\
\hline Scarborough North & $\mathrm{a}$ & $\mathrm{d}$ \\
\hline
\end{tabular}

$K=0.093)$ was far lower than the highest $K$ value at Groenrivier (Island Point, $K=0.198$ ). Four-year-old mussels achieved a maximum of $38 \mathrm{~mm}$ in the Cape Peninsula region, but $65 \mathrm{~mm}$ at Groenrivier (Fig. 4).

\section{Condition of Mytilus galloprovincialis at sites with different wave forces}

The condition indices of mussels at Groenrivier varied substantially among sites and over time (Fig. 5a). A 2-way ANOVA showed that the interaction between the sites and times was statistically significant (Table 3a). Tukey tests detected that mussels at the 2 sites in the middle of the wave-force scale, Island Wreck and Island Point, had significantly higher condition indices than mussels at any of the other sites on 4 of the 5 occasions measurements were made $(\mathrm{p}<0.05)$. On most occasions they were, however, not different from each other $(p>0.05$, see also Fig. 5a). The other sites differed from any other site 2 to 4 times $(p<0.05)$, but the differences were not consistent, with values for any particular site sometimes being greater than other sites and sometimes less. Strong differences also occurred over time, with the exception of Caravan
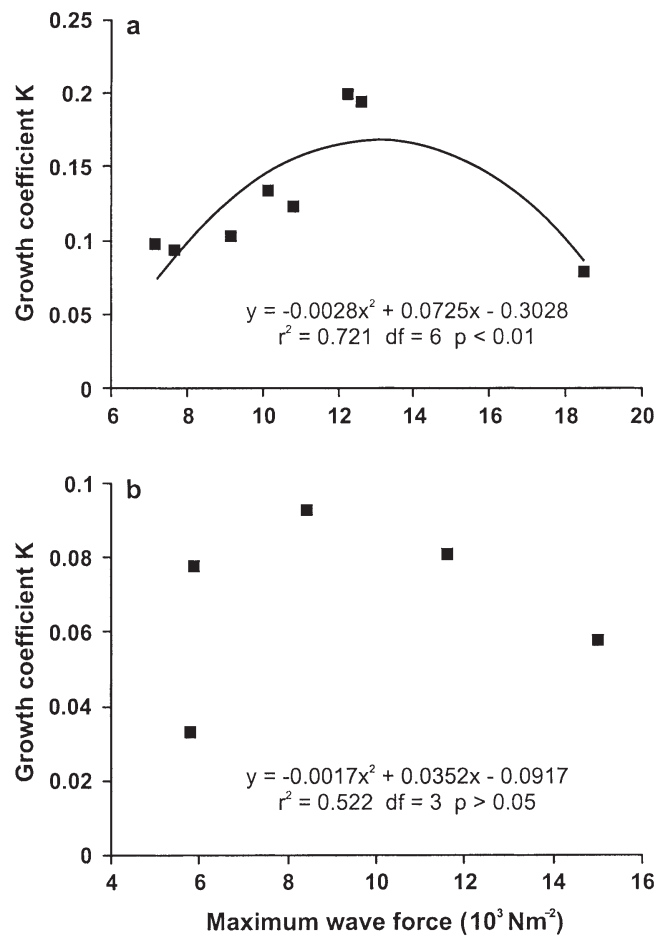

Fig. 4. Mytilus galloprovincialis. Growth coefficient $K$ in relation to maximum wave force at the sites (a) at Groenrivier and (b) on the Cape Peninsula

North, where mussels had similar condition indices during the entire study period ( $p>0.05)$. Seasonal patterns in condition indices were not very clear, with only a slight tendency towards lower values in spring (October 1998) and autumn (April 1999).

Condition indices of mussels in the region Cape Peninsula also varied over time and among sites (Fig. 5b). A 2-way ANOVA detected a significant interaction between sites and times (Table $3 \mathrm{~b}$ ). However, the pattern behind these differences was not as clear as at Groenrivier. Generally, differences among sites

Table 3. Mytilus galloprovincialis. 2-way Model-I ANOVA on the effects of Site and Time on the condition indices at (a) Groenrivier (data log-transformed) and (b) Cape Peninsula

\begin{tabular}{|lrrrr|}
\hline & df & \multicolumn{1}{c}{ MS } & \multicolumn{1}{c|}{$F$} & $\mathrm{p}$ \\
\hline (a) Groenrivier & & & & \\
Site & 7 & 10.546 & 242.243 & \\
Time & 4 & 5.323 & 122.278 & \\
Site $\times$ Time & 28 & 1.586 & 36.436 & $<0.001$ \\
Error & 1960 & 0.043 & & \\
(b) Cape Peninsula & & & & \\
Site & 4 & 3.002 & 73.489 & \\
Time & 4 & 5.829 & 142.701 & \\
Site $\times$ Time & 16 & 0.460 & 11.251 & $<0.001$ \\
Error & 1225 & 0.041 & & \\
\hline
\end{tabular}


on the Cape Peninsula were not as great as at Groenrivier, and at none of the sites were the average condition indices as high as at the 2 exposed sites Island Wreck and Island Point at Groenrivier. On the Cape Peninsula, mussels at the sites Shelter and Scarborough South usually had significantly higher condition indices than those at any of the other sites, and the most exposed site, Scarborough North, and the most sheltered site, Kommetjie, usually had the lowest values. Mussels at the site Witrock, in the middle of the wave-force scale, had low condition indices similar to those at the very sheltered and the very exposed sites (Fig. 5b). At all sites, lowest values occurred in January 1999 and April 1999.

\section{Shell shapes of Mytilus galloprovincialis at different wave forces}

The shapes of the Mytilus galloprovincialis shells varied significantly among the sites in both regions. Calculations of the shell height and the shell width of a standard $50 \mathrm{~mm}$ long mussel for each site (equations in Table 4) showed that in both regions mussels tended to be both taller and wider at more sheltered sites than at exposed sites (Fig. 6). This was especially apparent for shell height. The only exception occurred at Island Wreck at Groenrivier, where mussels had similar shapes to those from sheltered sites (Fig. 6a).

When the height $\left(y_{1}\right)$ and width $\left(y_{2}\right)$ of standard $50 \mathrm{~mm}$ long mussels were regressed on wave force $(x)$, there were no significant relationships with wave force (Groenrivier: $y_{1}, r^{2}=0.467 ; y_{2}, r^{2}=0.231 ; d f=6, p>0.05$ in both cases; Cape Peninsula: $y_{1}, \mathrm{r}^{2}=0.594 ; y_{2}, \mathrm{r}^{2}=$ $0.210 ; \mathrm{df}=3, \mathrm{p}>0.05$ in both cases).

ANCOVA (Table 5) and associated Tukey tests (see Fig. 6a) detected that at Groenrivier most regressions describing the relationships between length and height and between length and width at the various sites differed in either their slopes or their elevations. For the length/height relationship there tended to be 4 groups of sites: Caravan North, Round Rock and Island Wreck had the highest values, being significantly different from Esterhuizen, Tongue, and Sean's Site, which had the lowest values. Island Point and Caravan South were intermediate and significantly different from each other and the other groups (Fig. 6a). Length/width relationships fell into 4 groups, with Caravan North having the highest value, significantly greater than those at Round Rock, Island Wreck and Tongue, which were equivalently ranked and had significantly greater widths than mussels at Caravan South, Island Point and Esterhuizen. Mussels at Sean's Site had the lowest widths (Fig. 6a).
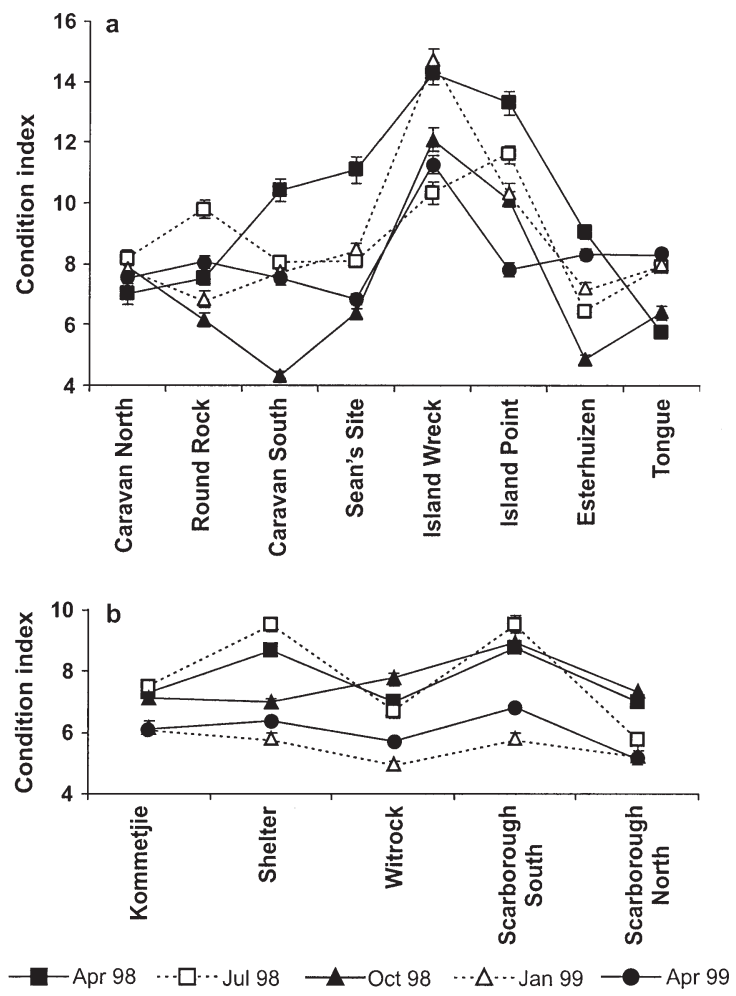

Fig. 5. Mytilus galloprovincialis. Condition indices (means \pm $\mathrm{SE}, \mathrm{n}=50$ ) at (a) Groenrivier and (b) Cape Peninsula. The lines connecting the symbols do not infer relationships among sites but are inserted to aid visualisation

On the Cape Peninsula, all length/height regression slopes were similar, but the elevations differed significantly (Table 5b). Mussels at the 3 more sheltered sites (Kommetjie, Shelter and Witrock) grouped together and were taller than at the 2 exposed sites (Scarborough South and Scarborough North). Mussels at all sites differed in their widths, except between Shelter and Scarborough North (Table 5b, Fig. 6b).

Between the 2 regions, no differences in shell shape were apparent. Standard $50 \mathrm{~mm}$ long mussels ranged in height from 23.1-25.1 $\mathrm{mm}$ at Groenrivier and 23.0-24.8 $\mathrm{mm}$ on the Cape Peninsula, and in width from $17.6-20.9 \mathrm{~mm}$ at Groenrivier and $19.2-21.8 \mathrm{~mm}$ on the Cape Peninsula.

The hydrodynamic force experienced by mussels in densely packed mussel beds is mainly lift, which acts perpendicular to the substratum (Denny 1987, Bell \& Gosline 1997). Mussels in beds are usually positioned with the long axis perpendicular to the substratum, so the area over which this force acts is determined by the width and the height of a mussel. This shell planform area $\left(A_{\mathrm{pl}}, \mathrm{cm}^{2}\right)$ can be approximated as an ellipse with shell height and shell width as the axes (Denny 1987). The calculation of the planform area for standard 
Table 4. Mytilus galloprovincialis. Relationships between shell length $(x, \mathrm{~mm})$ and shell height $(y, \mathrm{~mm}) ;$ shell length $(x, \mathrm{~mm})$ and shell width $(y, \mathrm{~mm})$; and shell surface area $\left(x, \mathrm{~cm}^{2}\right)$ and shell weight $(y, g)$ at (a) Groenrivier and (b) Cape Peninsula; $\mathrm{df}=242 \mathrm{for}$ all equations. Note that 'shell length' denotes anatomical height and 'shell height' denotes anatomical length

\begin{tabular}{|c|c|c|c|c|c|c|}
\hline Site & $\begin{array}{c}\text { Equation } \\
y \text { (height) }=\end{array}$ & $r^{2}$ & $\begin{array}{c}\text { Equation } \\
y \text { (width) }=\end{array}$ & $\mathrm{r}^{2}$ & $\begin{array}{c}\text { Equation } \\
y \text { (weight) }=\end{array}$ & $r^{2}$ \\
\hline \multicolumn{7}{|l|}{ (a) Groenrivier } \\
\hline Caravan North & $1.1829 x^{0.7807}$ & 0.928 & $0.4229 x^{0.9852}$ & 0.867 & $0.1067 x^{1.5561}$ & 0.973 \\
\hline Round Rock & $0.9799 x^{0.8291}$ & 0.950 & $0.2947 x^{1.0683}$ & 0.949 & $0.1307 x^{1.4942}$ & 0.968 \\
\hline Caravan South & $1.2017 x^{0.7614}$ & 0.896 & $0.3147 x^{1.0380}$ & 0.938 & $0.155 x^{1.4301}$ & 0.962 \\
\hline Sean's Site & $1.0767 x^{0.7882}$ & 0.949 & $0.3010 x^{1.0401}$ & 0.965 & $0.0981 x^{1.5452}$ & 0.983 \\
\hline Island Wreck & $0.9966 x^{0.8248}$ & 0.946 & $0.2788 x^{1.0803}$ & 0.946 & $0.0772 x^{1.6398}$ & 0.982 \\
\hline Island Point & $0.9495 x^{0.8264}$ & 0.974 & $0.3881 x^{0.9825}$ & 0.933 & $0.1081 x^{1.5301}$ & 0.976 \\
\hline Esterhuizen & $0.9159 x^{0.8266}$ & 0.952 & $0.3114 x^{1.0397}$ & 0.955 & $0.0986 x^{1.5569}$ & 0.978 \\
\hline Tongue & $1.0117 x^{0.7997}$ & 0.889 & $0.3511 x^{1.0163}$ & 0.912 & $0.1331 x^{1.4776}$ & 0.953 \\
\hline \multicolumn{7}{|l|}{ (b) Cape Peninsula } \\
\hline Kommetjie & $1.1594 x^{0.7761}$ & 0.934 & $0.3826 x^{1.0332}$ & 0.894 & $0.1635 x^{1.5420}$ & 0.935 \\
\hline Shelter & $0.9965 x^{0.8190}$ & 0.925 & $0.2461 x^{1.1288}$ & 0.934 & $0.1103 x^{1.6094}$ & 0.962 \\
\hline Witrock & $0.9815 x^{0.8261}$ & 0.887 & $0.2382 x^{1.1549}$ & 0.841 & $0.1304 x^{1.5842}$ & 0.936 \\
\hline Scarborough South & $0.9828 x^{0.8060}$ & 0.923 & $0.2789 x^{1.0815}$ & 0.954 & $0.1059 x^{1.5974}$ & 0.969 \\
\hline Scarborough North & $0.9217 x^{0.8234}$ & 0.914 & $0.2779 x^{1.1005}$ & 0.907 & $0.1507 X^{1.5129}$ & 0.935 \\
\hline
\end{tabular}

Table 5. Mytilus galloprovincialis. ANCOVA tests of relationships between shell length $(\mathrm{mm})$ and height $(\mathrm{mm})$; shell length $(\mathrm{mm})$ and width $(\mathrm{mm})$; and shell surface area $\left(\mathrm{cm}^{2}\right)$ and shell weight (g) (as an index of shell thickness) at (a) Groenrivier and (b) Cape Peninsula

\begin{tabular}{|c|c|c|c|c|c|c|}
\hline \multirow[b]{2}{*}{ Comparison among: } & \multicolumn{2}{|c|}{ Length vs height } & \multicolumn{2}{|c|}{ Length vs width } & \multicolumn{2}{|c|}{ Surface area vs weight } \\
\hline & Slopes & Elevations & Slopes & Elevations & Slopes & Elevations \\
\hline \multicolumn{7}{|l|}{ (a) Groenrivier } \\
\hline$F$ & 5.872 & 56.657 & 5.820 & 42.513 & 17.176 & 67.838 \\
\hline $\mathrm{df}_{\text {pooled }}$ & 1984 & 1984 & 1984 & 1984 & 1984 & 1984 \\
\hline $\mathrm{p}$ & $<0.001$ & $<0.001$ & $<0.001$ & $<0.001$ & $<0.001$ & $<0.001$ \\
\hline \multicolumn{7}{|l|}{ (b) Cape Peninsula } \\
\hline$F$ & 2.076 & 69.007 & 4.324 & 82.528 & 3.086 & 111.27 \\
\hline $\mathrm{df}_{\text {pooled }}$ & 1240 & 1240 & 1240 & 1240 & 1240 & 1240 \\
\hline $\mathrm{p}$ & $>0.05$ & $<0.001$ & $<0.01$ & $<0.001$ & $<0.05$ & $<0.001$ \\
\hline
\end{tabular}

site with slightly less heavy shells, and 4 sites experiencing intermediate wave forces, with lighter shells (Fig. 8a).

Shell thickness indices of mussels from the Cape Peninsula varied greatly among sites (Table 5a), and shells were also always thicker there than at Groenrivier. Mussels with a standard $20 \mathrm{~cm}^{2}$ surface area weighed 12.7 to $16.6 \mathrm{~g}$ (Fig. 8b). The mussels tended to have thicker shells at sheltered than at exposed sites, but there was a considerable variation in shell

$50 \mathrm{~mm}$ long mussels depicts a trend towards reduction in cross-sectional area with increasing wave force for both regions, which was significant when the data were pooled for both regions (Fig. 7).

The shell thickness indices of mussels at Groenrivier exhibited significant differences among sites (see ANCOVA results in Table 5a), although the shell weights of mussels with a standard surface area of $20 \mathrm{~cm}^{2}$ covered a relatively small range of 10 to $11.5 \mathrm{~g}$ (Fig. 8a, values calculated from equations in Table 4). A significant polynomial relationship was apparent: a decrease in shell thickness with increasing wave forces up to $11-13 \times 10^{3} \mathrm{~N} \mathrm{~m}^{-2}$. At higher wave forces, the shells again became thicker and reached values comparable to those of mussels at sheltered sites (Fig. 8a).

Tukey tests showed a grouping of 2 very sheltered and 1 very exposed site with heavy shells, 1 sheltered thickness along the gradient of wave exposure, and the relationship between shell thickness and wave force was not significant (Fig. 8b). Tukey tests detected differences in shell thickness of Mytilus galloprovincialis among all sites, except for mussels at Witrock and Scarborough North (Fig. 8b).

\section{DISCUSSION}

\section{Growth and condition of Mytilus galloprovincialis along a gradient of wave force}

Environmental conditions have major impacts on growth, reproduction and shell morphology of mussels (Bayne et al. 1983, Griffiths \& Griffiths 1987, Hawkins \& Bayne 1992, Seed \& Suchanek 1992). In our study, marked differences in the growth rates, condition and 

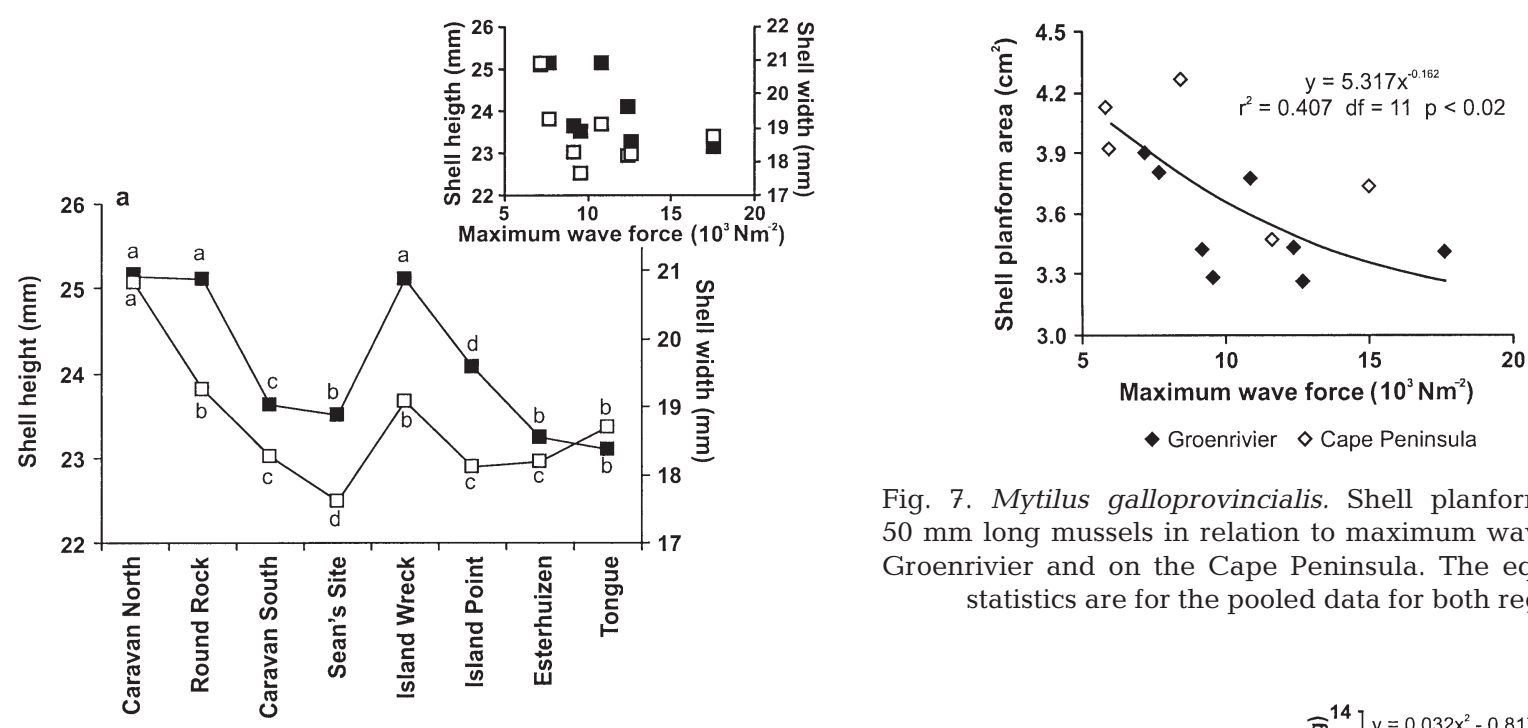

Fig. 7. Mytilus galloprovincialis. Shell planform areas of $50 \mathrm{~mm}$ long mussels in relation to maximum wave forces at Groenrivier and on the Cape Peninsula. The equation and statistics are for the pooled data for both regions
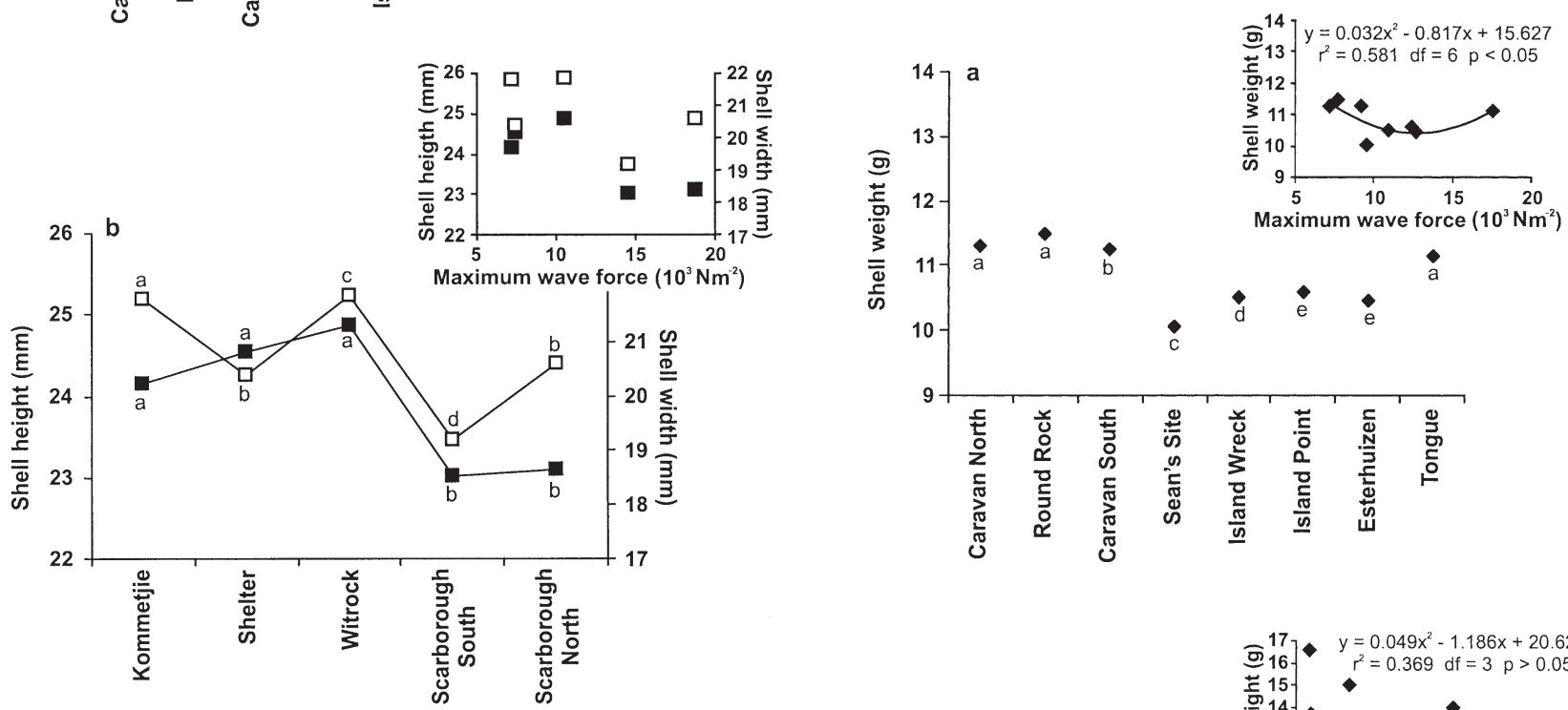

Fig. 6. Mytilus galloprovincialis. Shell height (匹) and width () of standard $50 \mathrm{~mm}$ long mussels at (a) Groenrivier and (b) Cape Peninsula. Heights and widths were calculated using the equations in Table 4 . Sites with shared letters were not significantly different in either their slopes or their elevations (Tukey tests, $p>0.05$ ). The lines connecting the symbols do not infer relationships among sites but are inserted to aid visualisation. Relationships of height or width to maximum wave force are depicted in the inset graphs

shell shapes of Mytilus galloprovincialis were detected among sites spanning a gradient of wave exposures. In 2 separate regions, mussels grew significantly faster at moderately exposed sites than at sheltered or extremely exposed sites, resulting in a polynomial relationship between the growth coefficient $K$ and average maximum wave force. Although apparent in both regions, this relationship was significant only at Groenrivier, and growth rates were also markedly greater there than at the Cape Peninsula.

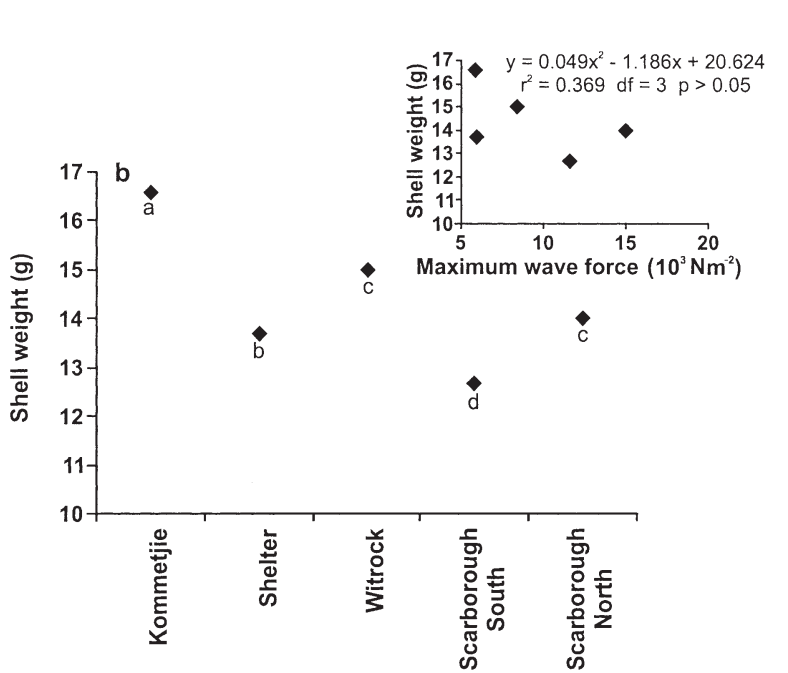

Fig. 8. Mytilus galloprovincialis. Shell weights of mussels with a standard surface area of $20 \mathrm{~cm}^{2}$ at (a) Groenrivier and (b) Cape Peninsula. Shell weights were calculated using the equations in Table 4. Sites with shared letters were not significantly different in either their slopes or elevations (Tukey tests, $p>0.05$ ). Relationships between shell weight and maximum wave force in the regions are given in the inset graphs 
Shell growth is not necessary coupled with tissue growth in bivalves. Indeed, shell growth can remain positive even in periods when tissue growth is negative (Fréchette \& Bourget 1985a, Borrero \& Hilbish 1988). The condition index, which relates the flesh weight to the amount of shell, is thus an important measure of the physiological status of mussels and the relative allocation of resources to tissue or shell growth (Raubenheimer \& Cook 1990, Seed \& Suchanek 1992). Condition values at Groenrivier showed the same trend as the growth rates, mussels at moderately exposed sites having significantly higher condition values than at sheltered or extremely exposed sites. On the Cape Peninsula, condition values were lower overall than at Groenrivier. Condition values were also reduced at both ends of the wave-force scale, but this pattern was not as clear-cut as at Groenrivier.

Several studies have recorded faster growth and better physiological condition of mussels and other intertidal filter-feeders in exposed compared to sheltered situations (Bertness et al. 1991, Robles \& Robb 1993, Sanford et al. 1994, Dahlhoff \& Menge 1996, Leichter \& Witman 1997, Sanford \& Menge 2001). In South Africa, growth of the indigenous mytilids Aulacomya ater, Choromytilus meridionalis and Perna perna and of the alien Mytilus galloprovincialis is faster in areas of high water circulation than in areas with restricted circulation (van Erkom Schurink \& Griffiths 1993).

Among sessile suspension feeders, food availability is generally the single most important environmental variable regulating production (Griffiths \& Griffiths 1987, Hawkins \& Bayne 1992). Surface waves are pressure waves that travel through the water surface and cannot themselves transport particles. Breaking surface waves can, however, transport particles. In the zone of the breaking waves, areas of high wave action experience greater water flows that both contain and transport more particulate matter than at sheltered shores and can quickly compensate for the effects of particle depletion over mussel beds (Fréchette \& Bourget 1985b, Fréchette et al. 1989, Bertness et al. 1991). The west coast of South Africa is fringed by dense forests of the kelps Ecklonia maxima (Osbeck) and Laminaria pallida (Grev. Ex J. Ag), which occur in the zone of the breaking waves and produce abundant detritus. At Groenrivier more than $50 \%$ of the carbon and $65 \%$ of the nitrogen assimilated by Mytilus galloprovincialis is derived from kelp detritus. Average concentrations of POM (65\% of which is kelp derived) and the rate of water turnover are greater on exposed than on sheltered shores (Bustamante \& Branch 1996). Thus, increased food supply at exposed sites may enable $M$. galloprovincialis to grow faster and allocate more energy to flesh production than at more sheltered sites, despite the likely greater metabolic costs of hav- ing to produce more byssus threads for stronger attachment.

At sites with extreme wave exposure, however, both growth and condition were markedly reduced. Decreases in growth of mussels and other bivalves on shores with heavy wave impact or in areas with very high water velocities have been reported elsewhere (Fox \& Coe 1943, Harger 1970, Wildish \& Saulnier 1992). Rate of ingestion by mussels increases with food availability until a threshold concentration of food particles is reached, above which the ingested ration remains relatively constant, and the 'surplus' filtered material is bound with mucus to form pseudofaeces that are expelled (Griffiths \& King 1979a, Griffiths \& Griffiths 1987, Hawkins \& Bayne 1992). Furthermore, at very high water velocities the filtration rate of bivalves is inhibited by hydrodynamic effects on the functioning of the bivalve pump (Wildish \& Saulnier 1992, Wildish et al. 1992, Newell \& Wildish 1997 , Newell et al. 2001). Hydrodynamic forces may also increase demands for byssus production or shell thickness, reducing the energy available for growth and production of mussels living on shores with heavy wave surge. Above certain thresholds, increases in water flow and food supply are therefore unlikely to have further positive effects on mussel growth, and may even have negative effects (Prins \& Smaal 1989).

The flesh weighed for the determination of the condition index included gametic tissue, and temporal changes in condition most likely reflected spawning events, rather than seasonal variation in food availability. The flesh dry weight of Mytilus galloprovincialis can vary 3-fold between ripe and spawned conditions (van Erkom Schurink \& Griffiths 1991), whereas kelpderived detritus, which forms an important part of this mussel's diet, is consistently high throughout the year (Bustamante \& Branch 1996).

Variations in growth and resource allocation are at least partially genetic (see review in Seed \& Suchanek 1992). However, mussels are broadcast spawners, and their larvae can spend 2 to $10 \mathrm{wk}$ in the plankton (Lutz \& Kennish 1992, Seed \& Suchanek 1992, Chícharo \& Chícharo 2000). Within each of the 2 regions examined, sites were not further apart than 5 to $8 \mathrm{~km}$, so it seems unlikely that sufficient isolation existed between the populations within the regions to achieve the genetic differentiation required for such an evolutionary response. Nevertheless, the fact that mussels on the Cape Peninsula all grew more slowly and never reached condition values as high as at Groenrivier may be due to genotypic differences. Alternatively, it may reflect differences in primary productivity related to the distribution of upwelling cells. Water along the west coast becomes increasingly clearer from the north to the south, and in the north the water contains more 
detritus, which is carried northwards by the Benguela System (Field et al. 1980). Benthic communities can be strongly influenced by the bottom-up influence of productivity (Menge et al. 1997, 1999, Menge 2000). For example, the difference in mussel growth rates on the Oregon coast, USA, between regions $80 \mathrm{~km}$ apart was attributed to variation in near-shore phytoplankton concentration (Dahlhoff \& Menge 1996). Similarly, the absence of mussels from much of the Cook Straits in New Zealand has been ascribed to the low seston quality there (Gardner 2000).

\section{Shell shape of Mytilus galloprovincialis}

In our study, growth rates were measured as length increments. However, body shape does not always change uniformly with an increase in length, but depends on the allometry of growth, and shell proportions do vary among mussel populations (Seed 1973, 1980, Brown et al. 1976, Hosomi 1985, Iwasaki 1996). Many factors influence shell shape, including crowding, trophic conditions, water depth, wave impact and presence of predators (Fox \& Coe 1943, Brown et al. 1976, Eager 1978, Seed 1978, Reimer et al. 1995, Akester \& Martel 2000).

Our results showed that, with some exceptions, mussel shells in both regions tended to be relatively taller and wider at sheltered sites than at exposed sites, although this pattern was not statistically related to wave action. For standard $50 \mathrm{~mm}$ long mussels, no relationship existed between relative shell height or shell width and the density of mussels ( $p>0.05$ in all cases, mussel-density data taken from Steffani \& Branch 2003). This suggests that crowding was not the underlying cause of differences in shell shape. Perhaps the trend towards lower and narrower shells at exposed sites reduces the area over which hydrodynamic lift acts and is a response to the increased risk of dislodgement (Denny 1987, Bell \& Gosline 1997), although this interpretation remains tentative.

Shell thickness also varied along the gradient of wave exposure. At least at Groenrivier, mussels of comparable size had thicker (heavier) shells at sheltered sites and extremely exposed sites, and thinner (lighter) shells at moderately exposed sites. This pattern was the inverse to that displayed by growth. The relationship between shell thickness and wave exposure contrasts with other studies. Akester \& Martel (2000), for instance, found that Mytilus trossulus had thicker shells and ligaments at exposed sites than at sheltered sites, and they suggested that this reduces the misalignment of the valves in areas with high wave energy. Raubenheimer \& Cook (1990) reported a greater shell thickness for subtidal Mytilus gallo- provincialis subjected to high wave action compared to populations in sheltered areas, and they concluded that any growth benefits accruing in exposed habitats may be channelled into increasing shell thickness rather than shell length. However, the mussel populations in our study had very different rates of growth and mussels of similar sizes were thus not of similar age. Differences in shell weight of mussels of similar length can be explained largely in terms of age, the older, slower-growing individuals having comparatively heavier shells than their younger, faster-growing counterparts (Seed 1980). This is supported by the inverse relationship of shell thickness with growth.

\section{Conclusions}

Mytilus galloprovincialis grew faster and had higher condition values at moderately exposed sites than at sheltered sites. This was most likely related to greater food availability at sites with greater water flow. However, at extremely exposed sites both growth rate and condition values were diminished. Growth rates and conditions of mussels on the Cape Peninsula were also low compared to those at Groenrivier, most likely due to lower food concentrations there. Mussel shells tended to be lower and narrower at more exposed sites, possibly reducing the impact of hydrodynamic forces. Shells were thickest at sheltered sites and at extremely exposed sites. This was inversely related to growth and is probably only indirectly, and not adaptively, related to wave action. Our most novel finding was the detection of a polynomial relationship between growth rate and wave force. Previous studies yielded conflicting conclusions about the effects of wave action of growth, because they compared a limited portion of the spectrum of wave action. Thus, our study shows the importance of incorporating the full range of conditions under which a species occurs, to understand the underlying causes of the patterns observed.

Mytilus galloprovincialis is an aggressively invasive alien species (Hockey \& van Erkom Schurink 1992, Griffiths et al. 1992). From our results, we predict that this mussel will have little impact on sheltered rocky shores because its growth, condition and density (Steffani \& Branch 2002) are low there due to inadequacies of food supply. Similarly, its effects at sites with extremely high wave action will also be limited: its growth and condition are low there because of inefficient feeding and diversion of energy into attachment and shell strength. Strong impacts of M. galloprovincialis are, however, anticipated at intermediate levels of wave action, where growth and condition are maximal. 
Acknowledgements. We thank C. Velasquez, S. Mayfield and J. Griffin for their enthusiastic assistance in the field. Funding was provided by grants from the University of Cape Town, the Mellon Foundation, the South African Network for Coastal and Oceanographic Research (SANCOR) and the National Research Foundation (NRF), and bursaries to C.N.S. from the NRF and the Marine Biology Research Institute. P. Petraitis, C. McQuaid and S. Navarette and 3 anonymous reviewers are gratefully acknowledged for comments on this paper.

\section{LITERATURE CITED}

Akester RJ, Martel AL (2000) Shell shape, dysodont tooth morphology, and hinge-ligament thickness in the bay mussel Mytilus trossulus correlate with wave exposure. Can J Zool 78:240-253

Bayne BL, Salkeld PN, Worrall CM (1983) Reproductive effort and value in different populations of the marine mussel, Mytilus edulis L. Oecologia 59:18-26

Bell EC, Gosline JM (1997) Strategies for life in flow: tenacity, morphometry, and probability of dislodgment of two Mytilus species. Mar Ecol Prog Ser 159:197-208

Bertness MD, Gaines SD, Bermudez D, Sanford ES (1991) Extreme spatial variation in the growth and reproductive output of the acorn barnacle Semibalanus balanoides. Mar Ecol Prog Ser 75:91-100

Borrero FJ, Hilbish TJ (1988) Temporal variation in shell and soft tissue growth of the mussel Geukensia demissa. Mar Ecol Prog Ser 42:9-15

Brown RA, Seed R, O'Connor RJ (1976) A comparison of relative growth in Cerastoderma (= Cardium) edule, Modiolus modiolus, and Mytilus edulis (Mollusca: Bivalvia). J Zool (Lond) 179:297-315

Bustamante RH, Branch GM (1996) The dependence of intertidal consumers on kelp-derived organic matter on the west coast of South Africa. J Exp Mar Biol Ecol 196: $1-28$

Chícharo LMZ, Chícharo MA (2000) Estimation of the life history parameters of Mytilus galloprovincialis (Lamarck) larvae in a coastal lagoon (Ria Formosa - South Portugal). J Exp Mar Biol Ecol 243:81-94

Dahlhoff EP, Menge BA (1996) Influence of phytoplankton concentration and wave exposure on the ecophysiology of Mytilus californianus. Mar Ecol Prog Ser 144:97-107

Davenport J, Chen X (1987) A comparison of methods for the assessment of condition in the mussel (Mytilus edulis L.). J Molluscan Stud 53:293-297

Dehnel PA (1956) Growth rates of latitudinally and vertically separated populations of Mytilus californianus. Biol Bull Woods Hole 110:43-53

Denny MW (1987) Lift as a mechanism of patch initiation in mussel beds. J Exp Mar Biol Ecol 113:231-245

Eager MC (1978) Shape and function of the shell: a comparison of some living and fossil bivalve molluscs. Biol Rev 53: $169-210$

Field JG, Griffiths CL (1991) Littoral and sublittoral ecosystems of southern Africa. In: Mathieson AC, Nienhuis PH (eds) Ecosystems of the World, Vol 24. Intertidal and Littoral Ecosystems. Elsevier, Amsterdam, p 323-346

Field JG, Griffiths CL, Griffiths RJ, Jarman N, Zoutendyk P, Velimirov B, Bowes A (1980) Variation in structure and biomass of kelp communities along the south-west Cape Coast. Trans R Soc S Afr 44:145-203

Fox DL, Coe WR (1943) Biology of the California sea-mussel (Mytilus californianus). J Exp Zool 93:205-249

Fréchette M, Bourget E (1985a) Food-limited growth of
Mytilus edulis L. in relation to the benthic boundary layer Can J Fish Aquat Sci 42:1166-1170

Fréchette M, Bourget E (1985b) Energy flow between the pelagic and benthic zones: Factors controlling particulate organic matter available to an intertidal mussel bed. Can J Fish Aquat Sci 42:1158-1165

Fréchette M, Butman CA, Geyer WR (1989) The importance of boundary-layer flows in supplying phytoplankton to the benthic suspension feeder, Mytilus edulis L. Limnol Oceanogr 34:19-36

Gardner JPA (2000) Where are the mussels on Cook Strait (New Zealand) shores? Low seston quality as a possible factor limiting multi-species distributions. Mar Ecol Prog Ser 194:123-132

Gardner JPA, Thomas MLH (1987) Growth, mortality and production of organic matter by a rocky intertidal population of Mytilus edulis in the Quoddy Region of the Bay of Fundy. Mar Ecol Prog Ser 39:31-36

Griffiths CL, Griffiths RJ (1987) Bivalvia. In: Pandian TJ, Vernberg FJ (eds) Animal energetics. Academic Press, New York, p 1-88

Griffiths CL, King JA (1979a) Some relationships between size, food availability and energy balance in the ribbed mussel Aulacomya ater. Mar Biol 51:141-149

Griffiths CL, King JA (1979b) Energy expended on growth and gonad output in the ribbed mussel Aulacomya ater. Mar Biol 53:217-222

Griffiths CL, Hockey PAR, van Erkom Schurink C, Roux PJL (1992) Marine invasive aliens on South African shores: implications for community structure and trophic functioning. S Afr J Mar Sci 12:713-722

Harger JRE (1970) The effect of wave impact on some aspects of the biology of sea mussels. Veliger 12:401-414

Hawkins AJS, Bayne BL (1985) Seasonal variation in the relative utilization of carbon and nitrogen by the mussel Mytilus edulis: budgets, conversion efficiencies and maintenance requirements. Mar Ecol Prog Ser 25:181-188

Hawkins AJS, Bayne BL (1992) Physiological interrelations, and the regulation of production. In: Gosling $\mathrm{E}$ (ed) The mussel Mytilus: ecology, physiology, genetics and culture. Elsevier, Amsterdam, p 171-222

Hockey PAR, van Erkom Schurink C (1992) The invasive biology of the mussel Mytilus galloprovincialis on the southern African coast. Trans R Soc S Afr 48:123-139

Hosomi A (1985) On several fundamental allometries of the mussel, Mytilus galloprovincialis. Venus 44:172-182

Hunt HL, Scheibling RE (2001) Predicting wave dislodgment of mussels: variation in attachment strength with body size, habitat, and season. Mar Ecol Prog Ser 213:157-164

Iwasaki K (1996) Vertical changes in density, size structure and shell shape of the bivalve Lasaea undulata within intertidal mussel beds. J Mar Biol Assoc UK 76:417-430

Jørgensen CB (1976) Growth efficiencies and factors controlling size in small mytilid bivalves, especially Mytilus edulis L.: review and interpretation. Ophelia 15:175-192

Leichter JJ, Witman JD (1997) Water flow over subtidal rock walls: relation to distributions and growth rates of sessile suspension feeders in the Gulf of Maine. J Exp Mar Biol Ecol 209:293-307

Lutz RA, Kennish MJ (1992) Ecology and morphology of larval and early postlarval mussels. In: Gosling E (ed) The mussel Mytilus: ecology, physiology, genetics and culture. Elsevier, Amsterdam, p 53-85

Menge BA (2000) Top-down and bottom-up community regulation in marine rocky intertidal habitats. J Exp Mar Biol Ecol 250:257-289

Menge BA, Daley BA, Wheeler PA, Strub PT (1997) Rocky 
intertidal oceanography: an association between community structure and nearshore phytoplankton concentration. Limnol Oceanogr 42:57-66

Menge BA, Daley BA, Lubchenco J, Sanford E, Dahlhoff E, Halpin PM, Hudson G, Burnaford JJ (1999) Top-down and bottom-up regulation of New Zealand rocky intertidal communities. Ecol Monogr 69:297-330

Newell CR, Wildish DJ (1997) The effects of current speed on exhalant siphon area and shell gape in blue mussels under constant seston regimes. J Shellfish Res 16:339

Newell CN, Wildish DJ, MacDonald BA (2001) The effects of velocity and seston concentration on the exhalant siphon area, valve gape and filtration rate of the mussel Mytilus edulis. J Exp Mar Biol Ecol 262:91-111

Paine RT, Levin SA (1981) Intertidal landscapes: disturbance and the dynamics of pattern. Ecol Monogr 51:145-178

Palumbi SR (1984) Measuring intertidal wave forces. J Exp Mar Biol Ecol 81:171-179

Peres-Neto PR (1999) How many statistical tests are too many? The problem of conducting multiple ecological inferences revisited. Mar Ecol Prog Ser 176:303-306

Price HA (1982) An analysis of factors determining seasonal variation in the byssal attachment strength of Mytilus edulis. J Mar Biol Assoc UK 62:147-155

Prins TC, Smaal AC (1989) Carbon and nitrogen budgets of the mussel Mytilus edulis L. and the cockle Cerastoderma edule (L.) in relation to food quality. Sci Mar 53:477-482

Raubenheimer D, Cook P (1990) Effects of exposure to wave action on allocation of resources to shell and meat growth by the subtidal mussel, Mytilus galloprovincialis. J Shellfish Res 9:87-93

Reimer O, Olsson B, Tedengren M (1995) Growth, physiological rates and behaviour of Mytilus edulis exposed to the predator Asterias rubens. Mar Behav Physiol 25: 233-244

Robles C, Robb J (1993) Varied carnivore effects and the prevalence of intertidal algal turfs. J Exp Mar Biol Ecol 166:65-91

Sanford E, Menge BA (2001) Spatial and temporal variation in barnacle growth in a coastal upwelling system. Mar Ecol Prog Ser 209:143-157

Sanford E, Bermudez D, Bertness MD, Gaines SD (1994) Flow, food supply and acorn barnacle population dynamics. Mar Ecol Prog Ser 104:49-62

Satterthwaite FE (1946) An approximate distribution of estimates of variance components. Biometrics Bull 2:110-114

Editorial responsibility: Roger Hughes (Contributing Editor), Bangor, Wales, UK
Seed R (1973) Absolute and allometric growth in the mussel Mytilus edulis L. (Mollusca: Bivalvia). Proc Malacol Soc Lond 40:343-357

Seed R (1976) Ecology. In: Bayne BL (ed) Marine mussels: their ecology and physiology. Cambridge University Press, Cambridge, p 13-65

Seed R (1978) The systematics and evolution of Mytilus galloprovincialis Lamarck. In: Beardmore JA, Battaglia B (eds) The genetics, ecology, and evolution of marine organisms. Plenum Press, New York, p 447-466

Seed R (1980) Shell growth and form in the Bivalvia. In: Rhoads DC, Lutz RA (eds) Skeletal growth of aquatic organisms: biological records of environmental change. Plenum Press, New York, p 23-61

Seed R, Suchanek TH (1992) Population and community ecology of Mytilus. In: Gosling E (ed) The mussel Mytilus: ecology, physiology, genetics and culture. Elsevier, p 87-169

Steffani CN (2001) Interactions between an indigenous limpet, Scutellastra argenvillei, and an alien invasive mussel, Mytilus galloprovincialis: moderation by wave action. $\mathrm{PhD}$ thesis, Zoology Department, University of Cape Town

Steffani CN, Branch GM (2003) Spatial comparisons of populations of an indigenous limpet Scutellastra argenvillei and the alien mussel Mytilus galloprovincialis along a gradient of wave energy. S Afr J Mar Sci (in press)

Suchanek TH (1985) Mussels and their role in structuring rocky shore communities. In: Moore RG, Seeds R (eds) The ecology of rocky coast. Hodder \& Stoughton Educational, London, p 70-96

Underwood AJ (1997) Experiments in ecology: their logical design and interpretation using analysis of variance. Cambridge University Press, Cambridge

van Erkom Schurink C, Griffiths CL (1991) A comparison of reproductive cycles and reproductive output in four southern African mussel species. Mar Ecol Prog Ser 76:123-134

van Erkom Schurink C, Griffiths CL (1993) Factors affecting relative rates of growth in four South African mussel species. Aquaculture 109:257-273

Wildish DJ, Saulnier AM (1992) The effect of velocity and flow direction on the growth of juvenile and adult giant scallops. J Exp Mar Biol Ecol 155:133-143

Wildish DJ, Kristmanson DD, Saulnier AM (1992) Interactive effect of velocity and seston concentration on giant scallop feeding inhibition. J Exp Mar Biol Ecol 155:161-168

Witman JD, Suchanek TH (1984) Mussels in flow: drag and dislodgement by epizoans. Mar Ecol Prog Ser 16:259-268

Submitted: June 4, 2001; Accepted: August 28, 2002

Proofs received from author(s): December 5, 2002 